\title{
Biologi Molekuler Human Papilloma Virus
}

\author{
Maya Savira*
}

\begin{abstract}
Persistent infection of the high-risk group Human Papilloma Virus (hrHPV) has been known to cause cervical cancer. Currently cervical cancer still ranks as the number two of most malignant disease in women. The infection of HPV that lead to cancer cells to form can be known through the structure of the HPV virus itself and what particles in the virus play a role in initiating the carcinogenic process of its host cell.
\end{abstract}

Key words: Human papillomavirus

Penelitian mengenai HPV dipicu tidak hanya karena infeksi yang muncul semakin luas secara diam-diam tanpa gejala yang jelas, tapi juga disebabkan oleh sejauh mana tingkat progresifitas keparahan dari penyakit terkait infeksi HPV. Hasil yang paling signifikan yaitu terjadinya kanker serviks, yang disebabkan oleh infeksi persisten dari grup high-risk Human Papilloma Virus (hrHPV). Grup low-risk Human Papilloma Virus (lrHPV) juga dapat menyebabkan penyakit yang cukup mengganggu bagi beberapa individu. ${ }^{1,2}$

Kanker serviks uteri merupakan penyakit keganasan kedua terbanyak pada wanita di dunia dengan estimasi sekitar 445.000 kasus baru dan sekitar 270.000 kematian pada tahun $2012 .{ }^{3}$ Sekitar $85 \%$ dari keseluruhan kasus kanker serviks ini terjadi di negara miskin dan berkembang, termasuk Indonesia. ${ }^{3}$ Di Indonesia, diperkirakan terdapat 98.962 total penderita kanker serviks pada tahun 2013. ${ }^{4}$ Diperkirakan sekitar 11.000 wanita didiagnosis menderita kanker serviks setiap tahunnya dan sepertiganya meninggal dunia. ${ }^{5}$ Infeksi HPV sendiri tidak cukup untuk menyebabkan kanker serviks tanpa didukung oleh faktor resiko seperti merokok, konsumsi kontrasepsi oral jangka panjang, koinfeksi, multiparitas, dan penyakit yang berhubungan dengan kelainan sistem imun. ${ }^{6}$

\footnotetext{
* Penulis untuk korespondensi :

KJF Mikrobiologi Fakultas Kedokteran Universitas Riau. Email : $\underline{\text { mayadonel@yahoo.co.id }}$
}

\section{Struktur Virus dan Kelompok Genom}

\section{Struktur virus}

Human Papillomavirus (HPV) merupakan virus DNA untai ganda yang memiliki 7900 bp, tidak berenvelop, dan merupakan famili papilomavi ridae. $^{7}$ Genom HPV terdiri dari 8 open reading frame yaitu 6 early genes dan 2 late genes. ${ }^{7}$ Dari 16 genus yang dimiliki famili papilomaviridae, 5 genus diantaranya menginfeksi manusia yaitu Alphapapillomavirus, Betapapillomavirus, Gammapapillomavirus, Mupapillomaviurs dan Nupapillomavirus. ${ }^{8}$ Human Papillomavirus yang paling sering ditemukan pada pasien berada dalam genus Alphapapillomavirus, hubungan antar genus tersebut lebih jelas tampak pada gambar $1 .{ }^{9}$

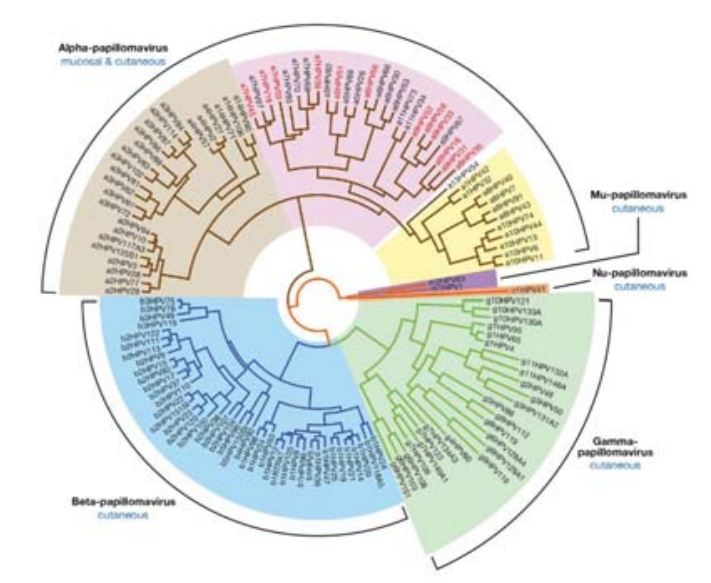

Gambar 1. Gambaran hubungan antar genus papilomavirus. Alpha-papilomavirus terbagi dalam 3 kelompok, low risk cutaneus (coklat muda), low risk mucosal (kuning), high-risk mucosal (merah muda). Bagian resiko tinggi yang diberi warna merah merupakan penyebab kanker pada manusia. ${ }^{10}$ 
Human papillomavirus (HPV) merupakan virus DNA non-envelop yang relatif kecil dengan ukuran sekitar 8000 bp dan manusia merupakan satu-satunya inang bagi virus ini. Genom HPV diselubungi oleh kapsid ikosahedral $(\mathrm{T}=7)$ dengan diameter 55nm, hanya mengkode 8 gen ( 8 ORFs), yaitu 6 gen pada Early gen (ER) dan 2 gen pada Late gen (LR). Early Region (ER), berisi gen yang mengkode protein non-struktur. Early region (ER) mengkode protein untuk bentuk virus atau proses replikasi, transkripsi virus dan regulasi gen virus serta bersifat onkogen. Early gen terbentuk dalam beberapa protein gen seperti: E1, E2, E4, E5, E6 dan E7. Late Region (LR), berisi gen yang mengkode protein pembentukan kapsid virus serta mengkode struktur protein. Late Region terbentuk dalam dua protein gen yaitu L1 dan L2 yang dikenal sebagai kapsid mayor (protein L1) dan kapsid minor (protein L2). ${ }^{11-13}$ Genom virus ini terdiri atas lingkaran episomes double-stranded dengan lebih kurang 8000 pasang pasangan basa. Walaupun jumlah gen yang dimiliki terbatas karena ukuran genomnya yang kecil, namun jumlah encodeproteins di dalamnya jauh lebih besar sesuai dengan ekspresi gen HPV yang melibatkan banyak promoter dan memiliki jalur kompleks untuk saling menyambung. ${ }^{14}$

Human Papillomavirus memiliki 6 gen pada Early Region (ER) dan 2 gen pada Late Region (LR ), dan pada LR terbentuk dalam protein L1 dan L2. Protein kapsid mayor L1 merupakan protein dengan ukuran $55 \mathrm{kD}$ yang memiliki kemampuan untuk membentuk diri menjadi virus like particle (VLP). ${ }^{6}$ Protein L1 berfungsi sebagai perantara reaksi antara virus dan Tissue specific heparin sulfate proteoglycan (HSPG) pada matriks ekstra seluler pada saat infeksi awal HPV. ${ }^{10}$ Evaluasi imunohistokimia dari protein L1 HPV berpotensi prognostik pada pasien yang terinfeksi HPV. Sedikit atau hilangnya ekspresi dari protein L1 merupakan pertanda akan berlanjutnya proses hingga menjadi karsinoma invasif, sedangkan ekspresi dari protein L1 merupakan pertanda bahwa lesi akan cenderung regresi dan beresiko rendah untuk menjadi karsinoma invasif. Hal ini sesuai dengan siklus hidup virus dimana L1 akan mengenkapsulasi genom virus dalam nukleus saat fase replikasi, membentuk progeni virus yang dapat menginisisasi infeksi. Kemudian diikuti oleh fase transformasi dimana terjadi integrasi antara genom virus dan sel pejamu. Beberapa assay yang berbeda telah dicoba untuk mendeteksi respon imun humoral yang spesifik terhadap protein kapsid L1.

Protein kapsid mayor L1 merupakan target protein bagi respon imun humoral dan berguna sebagai penanda untuk infeksi aktif HPV HPV. L1 dapat berubah sendiri menjadi VLP yang bersifat imunogenik dan merangsang reaksi antibodi. Partikel HPV mengandung protein L2 dengan jumlah yang bervariasi, yang tidak sepenuhnya terekspos pada permukaan virus, berbeda dengan asam amino dan protein N-terminal 120 yang dimiliknya. ${ }^{15,16}$ Selama proses infeksi, protein L2 akan tersedia untuk proses pengikatan/peleburan ke dalam matriks ekstraseluler, lalu kemudian ia akan dibelah oleh purin. ${ }^{17}$

Genom virus juga mengatur enkoding protein yang menstimulasi cell cycle entry dan proliferasi sel, sama halnya dengan protein yag memediasi genom virus untuk bereplikasi, pemasangan virus, dan kemungkinan juga efektif dalam pelepasan dan transmisi virus. Meskipun mayoritas dari gen tersebut sudah disimpan dalam early-region virus, produk gen L2 juga mempunyai kunci immediateearly functions dalam pengiriman genom virus di dalam sel dan juga berperan dalam mengatur penyusunan genom yang tepat. ${ }^{18}$

\section{Kelompok genom}

Protein E1 berperan dalam mempersiapkan genom virus untuk bereplikasi mengikuti siklus sel pejamu. Protein E2 menjaga bentuk sepisomal genom virus dan mengatur proses transkripsi, protein E4 memfasilitasi replikasi virus dan mengganggu sitoskeleton untuk mekanisme pengeluaran virion dari sel yang telah berdiferensiasi, protein E5 memodifikasi fungsi dari reseptor growth factor, protein E6 dan E7 merupakan komponen onkogenik utama dari genom HPV. produk E6 akan berikatan dengan tumor suppressor protein p53 dan membuat sel berada pada fase $\mathrm{S}$ pada siklus sel sehingga menghambat apoptosis dan meningkatkan kemampuan untuk bertransformasi. Protein E7 berikatan dengan tumor suppressor pRB yang menyebabkan tumorigenesis. ${ }^{6}$ 
Protein E5 dapat berinteraksi dengan jalur yang menginduksi epidermal growth factor receptor (EGFR). Ekspresi berlebihan dari EGFR akan meregulasi trankripsi gen dan memodulasi proliferasi sel, apoptosis, angiogenesis, invasi tumor, dan metastase melalui jalur Ras-Raf-MAP kinase dan jalur PI3K-Art. Ekpresi dari E5 juga dapat mengurangi ekspresi dari MHC/HLA kelas 1 yang memfasilitasi mekanisme penghindaran virus terhadap respon imun pejamu. Protein E5 juga dapat menghambat apoptosis oleh UV melalui peningkatan jalur MAP kinase dan PI3K-Art. Terakhir, protein E5 dapat menghambat apoptosis yang diinduksi hidrogen peroksida dengan cara menstimulasi ubiquitin dan mendegradasi protein Bax yang merupakan suatu protein pro apoptosis. ${ }^{19}$

Protein E6 memiliki target utama yaitu p53 yang merupakan tumor supresor. P53 berperan sebagai faktor transkripsi yang dapat menghentikan siklus sel atau memulai apoptosis akibat dari adanya kerusakan DNA. Normalnya, kondisi seperti kerusakan DNA akan meningkatkan kadar p53 untuk memulai apoptosis atau penghentian siklus sel. Protein E6 mengintervensi proses ini dengan cara berikatan dengan p53 dan E6-associated protein ligase (E6AP) menyebabkan ubiquitinilasi dan degradasi dari $\mathrm{p} 53$, hal ini sesuai dengan gambar $2 .{ }^{6}$

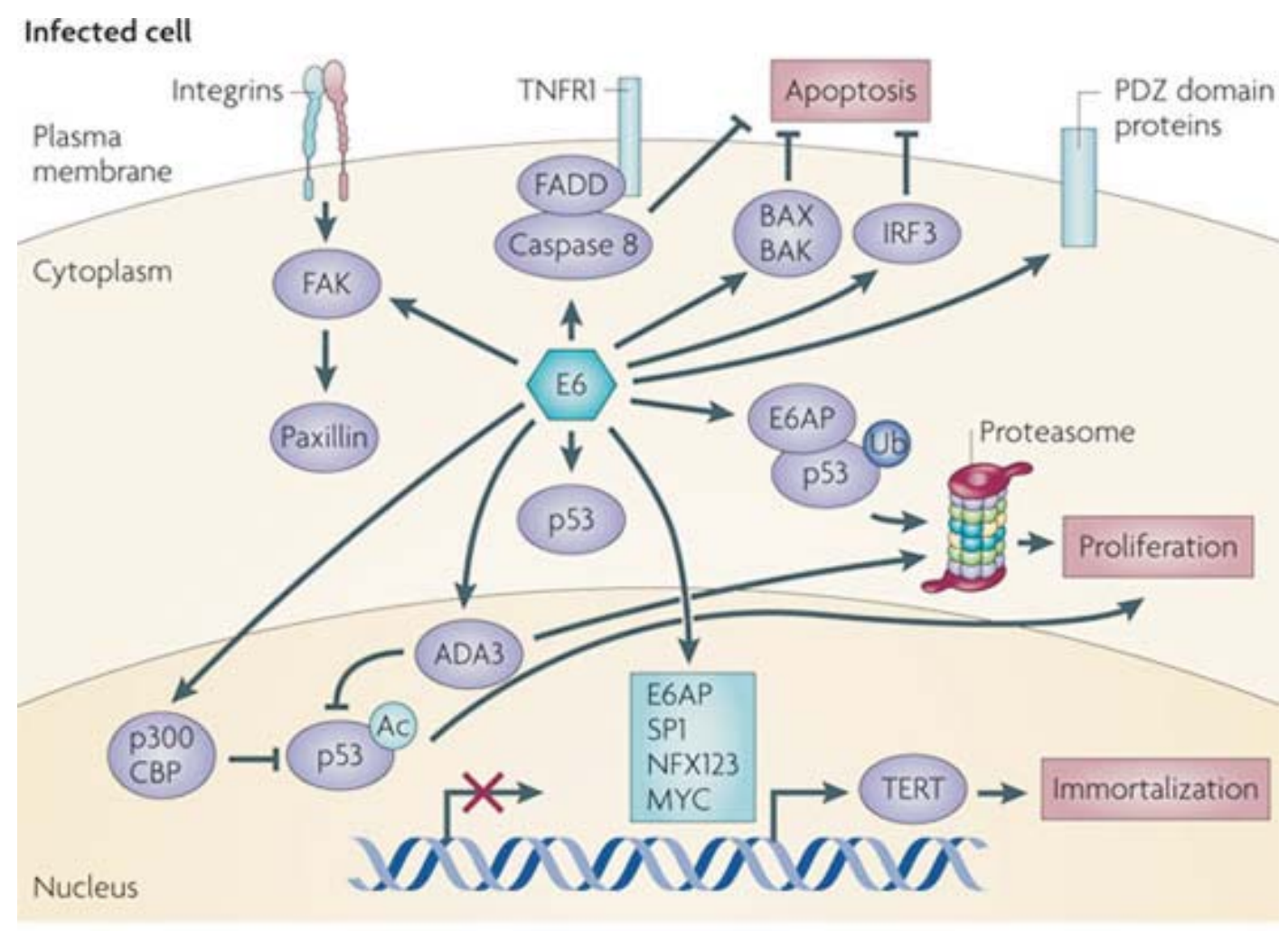

Gambar 2. Protein E6 menghambat p53 untuk menghentikan pertumbuhan dan melakukan apoptosis yang berujung pada instabilitas genom dan penumpukan mutasi seluler. Kompleks E6-E6AP-p53 akan berujung pada degradasi p53, dan interaksi E6 dengan histon asetiltransferase p300, CBP, dan ADA3 akan menghambat transkripsi dari gen p53. E6 juga menghambat sinyal apoptosis. Interaksi E6 dengan SP1, MYC, NFX123, dan E6AP akan mengaktivasi TERT dan telomerase, mencegah pemendekan telomere. E6 memodifikasi respon IFN dengan cara berinteraksi dengan IRF3 dan penghambatan aktivitas p53. FAK: focal adhesion kinase; ub: ubiquitin. ${ }^{11}$ 
Protein E7 merupakan suatu onkoprotein yang multifungsi mulai dari menghambat diferensisasi dan mengaktivasi siklus sel. Target utama dari protein E7 adalah protein retinoblastoma (pRb). Protein ini berikatan dengan faktor transkripsi E2F yang mengatur transisi dari fase G1 ke fase S. E2F yang teraktivasi akan membuat siklus sel memasuki fase S. protein E7 memiliki fungsi yang analog dengan fosforilasi $\mathrm{pRb}$ sehingga protein virus akan berikatan dengan $\mathrm{pRb}$ dan melepas E2F. Hal ini akan menyebabkan aktivasi dari gen yang esponsiv terhadap E2F yang mengkode baik siklus sel maupun replikasi virus. ${ }^{19}$ Fungsi masing-masing protein dirangkum dalam gambar 3 .

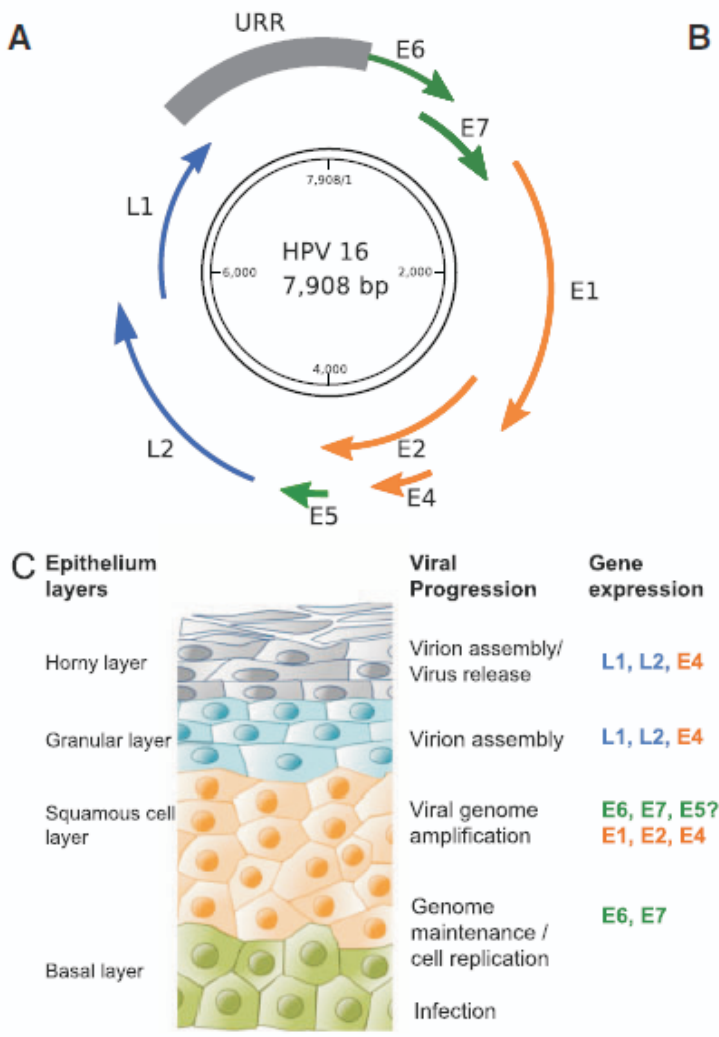

\begin{tabular}{|l|l|}
\hline Locus & \multicolumn{1}{|c|}{ Function } \\
\hline URR & $\begin{array}{l}\text {-Harbours transcription factor-binding sites } \\
\text {-Controls gene expression }\end{array}$ \\
\hline E6 & $\begin{array}{l}\text {-Promotes cellular immortalization by } \\
\text { degradation of p53 } \\
\text {-Modifies cell adhesion and differentiation } \\
\text { by degradation of TAp63 and p73 }\end{array}$ \\
\hline E7 & $\begin{array}{l}\text {-Promotes pRb degradation, permitting cell } \\
\text { progression to S-phase of cell cycle } \\
\text {-Induces chromosomal instability }\end{array}$ \\
\hline E5 & $\begin{array}{l}\text {-Induces cell proliferation } \\
\text {-Contributes to evasion of apoptosis } \\
\text {-Downregulates MHC expression }\end{array}$ \\
\hline E1 & $\begin{array}{l}\text {-ATP-dependent DNA helicase activity } \\
\text {-Role in viral DNA replication }\end{array}$ \\
\hline E2 & $\begin{array}{l}\text {-Coactivator of viral DNA replication } \\
\text {-Transcrition repressor of HPV E6 and E7 } \\
\text {-Regulates cell cycle and apoptosis } \\
\text {-Interacts with chromatin for segregation of } \\
\text { viral genome }\end{array}$ \\
\hline E4 & $\begin{array}{l}\text { Binds cytoskeletal proteins and disrupts } \\
\text { cytoskeletal structure of the G2 arrested cell }\end{array}$ \\
\hline L1 & $\begin{array}{l}\text {-Minor capsid protein } \\
\text {-Recruits L1 protein for virus assembly }\end{array}$ \\
\hline
\end{tabular}

Gambar 3. (A) Skema yang menggambarkan genom DNA untai ganda Papilloma virus, sebagai contoh HPV 16, menggambarkan posisi gen E, gen L, dan URR. (B) Ringkasan fungsi dari berbagai jenis gen pada papilomavirus. Hijau : onkogenesis, oren : gen replikasi virus, biru : gen kapsid virus. (C) Gambaran skematik dari siklus hidup HOV $16 .^{20}$

\section{Infeksi HPV}

Human papilloma Virus menginfeksi keratinosit pada stratum basal epitel serviks. Keratinosit pada traktus genital wanita mengekspresikan beberapa toll-like receptor (TLR), yang terdapat pada permukaaan selnya (TLR-1, TLR-2, TLR-4, TLR-5 dan TLR 6) atau pada endosomnya (TLR-3 dan TLR-9). TLR merupakan sistem imun yang mengenali pathogen-associated molecular patterns (PAMPs), aktivasi dari TLR akan memberikan sinyal untuk aktivasi jalur respon imun alami dan adaptif. TLR yang berada di endosom berperan dalam melawan infeksi virus dan mengenali asam nukleat dari virus; TLR-3 mengenali dsRNA, TLR-7 dan TLR-8 mengenali ssRNA, dan TLR-9 mengenali ds CpG-rich DNA. Aktivasi dari reseptor ini akan merangsang produksi dari sitokin dan membuat lingkungan proinflamatory. HPV dapat memodifikasi kadar sitokin untuk mekanisme penghindaran terhadap sistem imun ini. Aktivasi dari TLR-9 pada keratinosit menghasilkan produksi dari TNF-á, IL-8, CCL2, CXCL9, dan Interferon tipe 1. Tujuan utama dari HPV adalah untuk menurunkan respon imun pro 
inflamasi pada keratinosit serviks. Keratinosit memiliki kopi episomal dari HPV yang menggambarkan dalam jumlah yang besar gen yang terlibat dalam mekanisme pro inflamasi dan kemotaksis, gen yang menurunkan respon sel imun berperan dalam respon imun alami dan buatan demikian pula diferensiasi dari keratinosit. Hal ini menggambarkan pentingnya keratinosit sebagai inisiator dalam memulai respon imun terhadap HPV dan mengaktifvasi jalur respon imun adaptif. ${ }^{21}$

Sel pejamu dapat mengeliminasi sel yang terinfeksi melalui mekanisme apoptosis, akan tetapi 5 protein dari HPV yaitu E2, E5, E6, E6 dan E7 memiliki mekanisme untuk mengintervensi proses tersebut. Protein E2 merupakan faktor transkripsi dari virus dan berperan dalam replikasi virus. Protein E2 dapat menginduksi apoptosis pada sel yang tidak mengandung genom HPV melalui aktivasi dari caspase-8. E2 berikatan dengan caspase-8 domain DED dan menginisiasi aktivasi. Terdapat 2 karakteristik dari protein E2 yang berperan dalam apoptosis. Pertama, N-terminal dari HPV mengandung 27 asam amino alpha-helix yang dapat menginduksi oligomerisasi dan kematian sel. Kedua, protein E2 menginduksi apoptosis melalui mekanisme independen p53, E2 berikatan dengan p53 dan menginduksi apoptosis melalui jalur dependen p53. Ekspresi dari E2 pada lesi awal cukup rendah sehingga tidak cukup untuk menginduksi apoptosis. ${ }^{19}$

\section{Kesimpulan}

HPV merupakan virus DNA non-envelop yang relatif kecil dengan ukuran sekitar 8000 bp dan inang bagi virus ini adalah manusia. Protein L1 dan L2 pada HPV berperan sebagai titik untuk memulai siklus sel di sel inang. Aktivasi protein E1, E2, E4, E5, E6, E7 membantu proses replikasi sel virus, mencegah apoptosis dan mempengaruhi siklus sel inang melalui jalur lainnya sehingga terbentuklah mutasi sel yang berujung pada sel kanker.

\section{DAFTAR PUSTAKA}

1. Doorbar J, Quint W, Banks L, Bravo IG, Stoler M, Broker TR, et al. The biology and life cycle of human papillomaviruses. Vaccine 2012; 30 (Suppl. 5): 55-70.
2. Goon P, Sonnex C, Jani P, Stanley M, Sudhoff H. Recurrent respiratory papillomatosis, an overview of current thingking and treatment. Eur Arch Otorhinolaryngol 2008; 265(2):147-51.

3. Human papillomavirus (hpv) and cervical cancer. In: who media centre fact sheet (accsessed on August 2017). Available from: http:// www.who.int/mediacentre/factsheets/fs380/en/.

4. Infodatin-Stop Kanker 2013. Dalam: Pusat data dan informasi kementrian kesehatan RI (dilihat pada Agustus 2017). Dapat diakses dari: www.depkes.go.id. 2013.

5. Hong, Shiyuan, Laimonis A, Laimins. Regulation of the life cycle of HPV by differentiation and the DNA damage response. Future microbiology 2013; 8:1547-57.

6. Efthimios D, Aikaterini G, Nikolaos A, Vasileios K, Anastasia V, Konstantinos D, et al. HPV infection: Immunological aspects and their utility in future therapy. Infectious diseases in obstetrics and gynecology 2013:1-9.

7. Dan S, Hong L, Haibo L, Jianrong D. Effect of human papillomavirus infection on the immune system and its role in the course of cervical cancer. Oncology Letters 2015; 10(2): 600-6.

8. Abdullah, Qasim M, Shafiq M, Ijaz M, Parveen S, Murtaza S, et al. Molecular diagnosis and phylogenetic analysis of human papillomavirus type-16 from suspected patients in pakistan. Infect Agent Cancer 2016; 11: 1.

9. Wallace NA, Galloway DA. Manipulation of cellular DNA damage repair machinery cilitates propagation of human papillomaviruses.In: Cancer Biol 2014; 26: 30-42.

10.Egawa N, Egawa K, Griffin H, Doorbar J, et al. Human papillomaviruses; epithelial tropisms, and the development of neoplasia. Viruses 2015; 7(7):3863-90.

11. Moody CA, Laimins LA. Human papillomavirus oncoproteins: pathways to transformation. Nature reviews cancer 2010; 10: 550-60.

12.Burd EM. Human papillomavirus and cervical cancer. Clinical microbiology reviews 2003; 16 : $1-17$. 
13.Castellsagué X. Natural history and epidemiology of HPV infection and cervical cancer. Gynecologic oncology 2008; 110: 4-7.

14.Zheng ZM, Baker CC. Papillomavirus genome structure, expression, and post-transciptional regulation. Frontiers in Bioscience 2006; 11: 2286-302.

15.Rubio I, Seitz H, Canali E, Sehr P, Bolchi A, Tommasino M, et al. The N-terminal region of the human papillomavirus L2 protein contains overlapping binding sites for neutralizing, crossneutralizing and non-neutralizing antibodies.In: Virology 2011;409(2):348-59.

16.Liu WJ, Gissmann L, Sun XY, Kanjanahaluethai A, Müller M, Doorbar J, et al. Sequence close to the $\mathrm{N}$-terminal of $\mathrm{L} 2$ protein is displayed on the surface of bovine papillomavirys type 1 virions. Virology 1997; 227(2): 474-83.

17.Kines RC, Thompson CD, Lowy DR, Schiller JT, Day PM. The initial steps leading to papillomavirus infection occur on the basement membrane prior to cell surface binding. Proceedings of the national academy of the united states of america 2009; 106(48): 2045863.

18. Wang JW, Roden RB. L2, the minor capsid protein of papillomavirus. Virology 2013;445(12):175-86.

19.Zhao Q, Yorgo M, Katrina H, Victoria T, Yuan M, Yang W, et al. Disassembly and reassembly of Human Papillomavirus virus-like particles produces more virion-like antibody reactivity. Virology Journal 2012;9:52.

20.Bravo, Ignacio G, Marta FS. Papillomaviruses: viral evolution, cancer and evolutionary medicine. Evol Med Public Health 2015;1:3251.

21. Molina A, José FH, Edmundo L, Adriana CP, Marcela L. Role of innate immunity against Human Papillomavirus (HPV) infections and effect of adjuvants in promoting specific immune response. Viruses 2013; 5(11): 2624-42. 